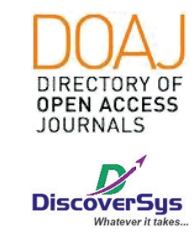

Published by DiscoverSys

\section{Profil kepadatan tulang wanita menopause di RSUP Sanglah Denpasar pada tahun 2017}

\author{
Ellintang Charisma Dewi, ${ }^{1 *}$ IGL Ngr Agung Artha Wiguna, ${ }^{2}$ I Wayan Niryana ${ }^{2}$
}

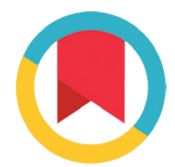

CrossMark

\title{
ABSTRACT
}

Background: Bone is a living tissue in the body that will continue to grow. A decrease in bone mass is identified from bone density and changes in bone structure. In addition to the growth process, bone is also regenerated. The process is affected by hormones. However, in menopause, resorption exceeds formation resulting in loss of bone mass and the risk of osteoporosis. Quoted from WHO, there are about 200 million people suffering from osteoporosis worldwide. Osteoporosis prevalence in Indonesia in 2004 reached 19.7\%.

Aim: The general purpose of this study was to determine profile of bone density in menopause women at General Hospital Sanglah Denpasar in 2017.

Methods: This study used a prospective observational design with an interview approach. The research was conducted in Obgyn Polyclinic
General Hospital Sanglah in August 2017. Instrument used in the form of Sonost 3000-Quantitative Ultrasound BMD, performed on the bone of calcaneus. Statistical analysis was done using SPSS.

Results: The results of 100 samples of menopausal women showed that the average age of the sample was 52.2 years old, the average of last menstrual period was 7 years, most were Balinese ethnic (84\%), most had last education status in the form of college (34\%), most were not working (42\%), and most had history of cervical cancer (49\%).

Conclusion: The average T-score was -1.7 with the highest proportion of osteopenia, followed by normal bone density and osteoporosis. Menopausal women with osteopenia has the most of normal BMI (37\%), while the percentage of menopausal women with osteoporosis is $13 \%$.

Keywords: bone density, T-score, menopause

Cite This Article: Dewi, E.C., Wiguna, I.G.L.N.G.R.A.A., Niryana, I.W. 2020. Profil kepadatan tulang wanita menopause di RSUP Sanglah Denpasar pada tahun 2017. Intisari Sains Medis 11(2): 918-922. D0I: 10.15562/ism.v11i2.233

\section{ABSTRAK}

Latar belakang: Tulang merupakan jaringan hidup dalam tubuh yang terus menerus akan mengalami pertumbuhan. Penurunan massa tulang diidentifikasikan dari kepadatan tulang dan perubahan struktur tulang. Selain proses pertumbuhan, tulang juga mengalami regenerasi. Proses tersebut dilakukan oleh hormon. Namun pada menopause, resorpsi melebihi pembentukan yang mengakibatkan hilangnya massa tulang dan risiko terjadinya osteoporosis. Dikutip dari WHO, ada sekitar 200 juta orang yang menderita osteoporosis di seluruh dunia. Prevalensi osteoporosis di Indonesia pada tahun 2004 mencapai 19,7\%.

Tujuan: Tujuan umum penelitian ini adalah untuk mengetahui profil kepadatan tulang wanita menopause di RSUP Sanglah Denpasar pada tahun 2017.

${ }^{1}$ Program Studi Pendidikan Dokter Fakultas Kedokteran Universitas Udayana

${ }^{2}$ Bagian/SMF IImu Bedah Fakultas Kedokteran Universitas Udayana/ RSUP Sanglah, Denpasar

${ }^{*}$ Correspondence to:

Ellintang Charisma Dewi, Program Studi Pendidikan Dokter Fakultas Kedokteran Universitas Udayana ellintangdewi@gmail.com

Diterima: 08-04-2018

Disetujui: $15-06-2018$

Diterbitkan: 01-08-2020
Metode: Desain penelitian ini menggunakan rancangan observasional prospektif dengan pendekatan wawancara. Penelitian dilakukan di Poliklinik Obgyn RSUP Sanglah pada bulan Agustus 2017. Instrumen yang digunakan berupa BMD Sonost 3000-Quantitative Ultrasound, yang dilakukan pada tulang calcaneus. Analisa data secara statistik menggunakan SPSS.

Hasil: Hasil penelitian dari 100 orang sampel menunjukkan bahwa rata-rata usia sampel wanita menopause yaitu 52,2 tahun, dengan rata-rata riwayat menstruasi terakhir 7 tahun, memiliki suku Bali 84\%, dengan status pendidikan terakhir berupa perguruan tinggi sebanyak $34 \%$, tidak bekerja sebanyak $42 \%$, dan memiliki riwayat penyakit terbanyak berupa kanker serviks yaitu $49 \%$.

Kesimpulan: Dari hasil T-score, didapatkan rata-rata $T$-score yaitu -1.7 dengan proporsi terbanyak adalah wanita dengan osteopenia, diikuti dengan kepadatan tulang normal dan osteoporosis. Wanita menopause dengan osteopenia memiliki IMT normal terbanyak (37\%), dan wanita menopause dengan osteoporosis memiliki IMT normal sebanyak $13 \%$.
Kata kunci: kepadatan tulang, T-score, menopause

Cite Pasal Ini: Dewi, E.C., Wiguna, I.G.L.N.G.R.A.A., Niryana, I.W. 2020. Profil kepadatan tulang wanita menopause di RSUP Sanglah Denpasar pada tahun 2017. Intisari Sains Medis 11(2): 918-922. D0I: 10.15562/ism.v11i2.233

\section{PENDAHULUAN}

Tulang merupakan jaringan hidup dalam tubuh yang terus menerus akan mengalami pertumbuhan. ${ }^{1}$ Seiring dengan bertambahnya usia, khususnya pada menopause, resorpsi melebihi pembentukan tulang yang mengakibatkan hilangnya massa tulang, dan dapat meningkatkan risiko terjadinya 
osteoporosis dari waktu ke waktu. ${ }^{2}$ Menopause terjadi karena ovarium berhenti memproduksi estrogen sehingga mengakibatkan kadar estrogen menurun dan terhentinya periode menstruasi. Menopause juga dapat terjadi apabila ovarium dibuang pada saat operasi atau berhentinya fungsi dari ovarium oleh karena sebab lain. Gejala jangka panjang yang terjadi diantaranya penyakit kardiovaskuler, demensia Alzheimer, dan osteoporosis. ${ }^{3}$

Osteoporosis adalah penyakit tulang sistemik yang ditandai dengan massa tulang yang rendah dan kerusakan mikroarsitektur jaringan tulang yang dapat meningkatkan risiko fraktur. ${ }^{4}$ Hasil penelitian yang telah dilakukan oleh Puslitbang Gizi Departemen Kesehatan Indonesia pada tahun 2004 di 14 provinsi menunjukkan bahwa kejadian osteoporosis di Indonesia telah mencapai tingkat yang perlu diwaspadai, yaitu sebesar $19,7 \%{ }^{5}$

Secara khusus, osteoporosis pada lanjut usia dikarakteristikan dengan rendahnya nilai kepadatan tulang dan degenerasi mikroarsitektur yang dapat meningkatkan kerapuhan dan risiko terjadinya patah tulang. ${ }^{6}$ World Health Organization (WHO) membagi nilai kepadatan tulang berdasarkan T-score menjadi: normal (lebih dari -1 SD atau Standar Deviasi), osteopenia (-1 sampai -2.5 SD), dan osteoporosis (dibawah -2.5 SD). ${ }^{7}$ Faktor risiko osteoporosis dikategorikan menjadi dua, yaitu faktor yang tidak dapat diubah seperti riwayat keluarga, jenis kelamin, usia, ras Asia dan Kaukasia, menopause, dan BMI, serta faktor yang dapat diubah seperti, kurangnya aktifitas fisik, asupan kalsium rendah, kekurangan protein, kurang asupan vitamin $\mathrm{D}$, alkohol, merokok, konsumsi kafein, dan penggunaan obat-obatan. ${ }^{8}$ Penelitian ini dilakukan untuk mengetahui profil kepadatan tulang wanita menopause di RSUP Sanglah Denpasar pada tahun 2017.

\section{METODE}

Penelitian ini merupakan penelitian deskriptif dengan menggunakan desain rancangan observasional prospektif dengan pendekatan wawancara yang dilakukan di Rumah Sakit Umum Pusat (RSUP) Sanglah Denpasar. Kriteria inklusi yang digunakan yaitu kesadaran baik, wanita yang sudah mengalami menopause, wanita yang berada di Poliklinik Obstetri dan Ginekologi, serta wanita yang bersedia menjadi responden. Kriteria eksklusi yang digunakan yaitu wanita yang belum menopause serta wanita yang tidak bersedia dilakukan wawancara dan pemeriksaan.

Data yang diperoleh berupa data primer berdasarkan hasil pengukuran BMD Sonost 3000-Quantitative Ultrasound pada tulang calcaneus dan hasil wawancara responden pada tahun 2017. Data yang dicari meliputi biodata sampel, nilai kepadatan tulang, dan Indeks Massa Tubuh (IMT). Data yang memenuhi kriteria inklusi diambil sebagai sampel penelitian. Data yang terkumpul kemudian dianalisis secara deskriptif dengan software SPSS versi 21 dan disajikan dalam bentuk tabel.

\section{HASIL}

\section{Karakteristik Sosiodemografis Sampel Penelitian}

Penelitian ini dilakukan pada 100 orang wanita menopause di Poliklinik Obstetri dan Ginekologi RSUP Sanglah pada tahun 2017 menggunakan BMD Sonost 3000-Quantitative Ultrasound pada tulang calcaneus.

Pada Tabel 1 didapatkan bahwa rata-rata usia sampel wanita yang sudah menopause adalah 52.2 tahun. Sejumlah 80 orang (80\%) sampel beragama Hindu dan sebanyak $84 \%$ merupakan suku Bali. Rata-rata IMT subyek penelitian adalah 24.4, dengan IMT tertinggi pada kategori normal sebanyak 58 orang.

Berdasarkan status pendidikan, didapatkan tingkat pendidikan tertinggi adalah perguruan tinggi (34\%). Ditinjau dari segi pekerjaan, presentase yang tidak bekerja adalah $42 \%$. Berdasarkan status pernikahan, sebanyak $80 \%$ sampel sudah menikah.

Rata-rata riwayat menstruasi terakhir pada sampel adalah 7 tahun. Dari penelitian ini, didapatkan riwayat penyakit berupa kelainan obgyn tertinggi yaitu kanker serviks (49\%), sedangkan untuk kelainan non-obgyn tertinggi berupa sakit lain-lain (7\%). Sebanyak (19\%) sampel penelitian tidak memiliki riwayat penyakit.

\section{Karakteristik Klinis Sampel Penelitian}

Tabel 2 memperlihatkan distribusi proporsi wanita menopause berdasarkan profil kepadatan tulang dilihat dari T-score di RSUP Sanglah pada tahun 2017. Dari 100 sampel wanita menopause yang telah dilakukan pengukuran, didapatkan hasil ratarata $T$-score yaitu -1.7, dengan proporsi osteopenia paling tinggi yaitu 52 orang (52\%) dibandingkan dengan kepadatan tulang normal 24 orang $(24 \%)$ dan osteoporosis 24 orang (24\%).

Tabel 3 menunjukkan bahwa pada wanita menopause dengan kepadatan tulang normal kategori IMT terbanyak dimiliki oleh wanita gemuk (11\%), pada osteopenia kategori IMT terbanyak dimiliki wanita normal (37\%), dan pada osteoporosis kategori IMT terbanyak dimiliki oleh wanita normal sebanyak (13\%). 
Tabel 1 Distribusi proporsi wanita menopause berdasarkan sosiodemografi

\begin{tabular}{|c|c|}
\hline Karakteristik & Jumlah (\%) \\
\hline Usia & $52.2 \pm 7.9^{*}$ \\
\hline$<40$ & $5(5)$ \\
\hline $41-50$ & $39(39)$ \\
\hline $51-60$ & $43(43)$ \\
\hline $61-70$ & $11(11)$ \\
\hline$>70$ & $2(2)$ \\
\hline \multicolumn{2}{|l|}{ Agama } \\
\hline Hindu & $80(80)$ \\
\hline Budha & $1(1)$ \\
\hline Islam & $13(13)$ \\
\hline Katolik & $1(1)$ \\
\hline Kristen & $5(5)$ \\
\hline \multicolumn{2}{|l|}{ Suku } \\
\hline Bali & $84(84)$ \\
\hline Bima & $4(4)$ \\
\hline Jawa & $6(6)$ \\
\hline Lain-lain & $6(6)$ \\
\hline \multicolumn{2}{|l|}{ Pendidikan Terakhir } \\
\hline Perguruan Tinggi & $34(34)$ \\
\hline SLTA & $25(25)$ \\
\hline SLTP & $8(8)$ \\
\hline SD & $24(24)$ \\
\hline Tidak Sekolah & $9(9)$ \\
\hline \multicolumn{2}{|l|}{ Pekerjaan } \\
\hline Pedagang & $7(7)$ \\
\hline Petani & $10(10)$ \\
\hline PNS & $29(29)$ \\
\hline Pegawai Swasta & $4(4)$ \\
\hline Wiraswasta & $1(1)$ \\
\hline Lain-lain & $7(7)$ \\
\hline Tidak Bekerja & $42(42)$ \\
\hline \multicolumn{2}{|l|}{ Status Pernikahan } \\
\hline Belum Menikah & $3(3)$ \\
\hline Menikah & $80(80)$ \\
\hline Janda & $17(17)$ \\
\hline Menstruasi Terakhir ${ }^{\star *}$ & $7 \pm 6.3^{*}$ \\
\hline
\end{tabular}

Tabel 1 Continue

\begin{tabular}{lc}
\hline Karakteristik & Jumlah (\%) \\
\hline Riwayat Penyakit & \\
Kelainan Obgyn & \\
Kanker Serviks & $49(49)$ \\
Kanker Ovarium & $8(8)$ \\
Kanker Payudara & $1(1)$ \\
Kista Ovarium & $4(4)$ \\
Mioma Uteri & $1(1)$ \\
Prolaps Uteri & $1(1)$ \\
Kelainan Non-Obgyn & \\
Asam Urat & $2(2)$ \\
Maag & $5(5)$ \\
Hipertensi & $3(3)$ \\
Lain-lain & $7(7)$ \\
Tidak ada & $19(19)$ \\
IMT\# & $24 \pm 18.7^{\star}$ \\
Kurus & $12(12)$ \\
Normal & $58(58)$ \\
Gemuk & $24(24)$ \\
Obesitas & $6(6)$ \\
\hline &
\end{tabular}

* mean \pm SD; ${ }^{* *}$ tahun; \# IMT $=$ Indeks Masa Tubuh

Tabel 2 Distribusi proporsi wanita menopause berdasarkan profil kepadatan tulang dilihat dari T-score di RSUP Sanglah pada tahun 2017

\begin{tabular}{lc}
\hline Kepadatan Tulang & Jumlah (\%) \\
\hline T-score & $-1.7 \pm 1.1^{\star}$ \\
Normal & $24(24)$ \\
Osteopenia & $52(52)$ \\
Osteoporosis & $24(24)$ \\
\hline
\end{tabular}

${ }^{*}$ mean $\pm \mathrm{SD}$

Tabel 3 Distribusi proporsi kepadatan tulang wanita menopause berdasarkan Indeks Massa Tubuh (IMT)

\begin{tabular}{lcccc}
\hline \multirow{2}{*}{$\begin{array}{l}\text { Kepadatan } \\
\text { Tulang }\end{array}$} & \multicolumn{4}{c}{ Indeks Massa Tubuh (\%) } \\
\cline { 2 - 5 } & Kurus & Normal & Gemuk & Obesitas \\
\hline Normal & $0(0)$ & $8(8)$ & $11(11)$ & $5(5)$ \\
Osteopenia & $2(2)$ & $37(37)$ & $12(12)$ & $1(1)$ \\
Osteoporosis & $10(10)$ & $13(13)$ & $1(1)$ & $0(0)$ \\
\hline
\end{tabular}




\section{DISKUSI}

Pada penelitian ini dapat dilihat bahwa rata-rata usia sampel wanita yang sudah menopause adalah 52.2 tahun. Hal ini sesuai dengan teori yang ada, bahwa rata-rata usia dari periode terhentinya masa haid secara alamiah terjadi pada usia 51 tahun. ${ }^{9}$ Kejadian tersebut dipengaruhi oleh kadar hormon estrogen dalam tubuh yang mulai menurun sejak usia 35 tahun. ${ }^{10}$

Rata-rata riwayat menstruasi terakhir pada sampel wanita menopause di Poliklinik Obstetri dan Ginekologi RSUP Sanglah adalah 7 tahun. Dari penelitian ini, didapatkan bahwa riwayat penyakit terbanyak pada wanita menopause adalah kanker serviks (49\%). Berlandaskan teori dari Sarwono (2007), terdapat dua jenis menopause yaitu menopause prematur atau disebut juga menopause dini, dan menopause terlambat. Menopause prematur terjadi sebelum wanita berusia 40 tahun, dimana biasanya haid telah berhenti antara umur 35-40 tahun. Faktor-faktor menopause prematur yaitu herediter, gangguan gizi yang cukup berat, penyakit-penyakit menahun, dan penyakit-penyakit yang merusak jaringan kedua ovarium. Kejadian tersebut dapat dikaitkan dengan banyaknya wanita menopause dengan riwayat penyakit kanker serviks yang tidak menutup kemungkinan melakukan pengangkatan rahim (histerektomi). Setelah mengalami histerektomi, pasien tidak akan mengalami haid kembali atau mengalami kehamilan. ${ }^{11}$

Berdasarkan hasil penelitian yang diperoleh dari pengukuran 100 wanita menopause didapatkan sebagian besar responden dikategorikan memiliki kepadatan tulang rendah (osteopenia), yaitu sebanyak $51 \%$. Sampel penelitian dengan kepadatan tulang normal adalah sebanyak $25 \%$, sedangkan $24 \%$ sampel dikategorikan mengalami osteoporosis. Hasil penelitian ini didukung dengan data penelitian yang dilakukan oleh Andriani (2016) di Jakarta dimana dari 110 responden didapatkan sebagian besar responden memiliki kepadatan tulang tidak normal (101 responden atau 91.8\%). Kondisi tersebut didominasi oleh responden yang menderita osteopenia (51.8\%) dibandingkan yang mengalami osteoporosis (40\%). Sedangkan 9 responden (8.2\%) dikategorikan memiliki kepadatan tulang normal. ${ }^{12}$

Pada kondisi osteopenia, BMD mulai mengalami penurunan dan kerapuhan tulang. Tingginya prevalensi dalam penelitian ini sejalan dengan tinggi prevalensi osteopenia di Indonesia yang mencapai $41.7 \% .^{12}$ Kondisi tersebut berhubungan dengan wanita yang mendekati masa menopause dimana produksi hormon estrogen, hormon progesteron, dan hormon seks lainnya mulai menurun. ${ }^{2}$ Perubahan tersebut mendasari terjadinya kehilangan massa tulang mencapai $2.5-5 \%$ setahun selama 4-5 tahun setelah menopause. Secara keseluruhan wanita akan kehilangan massa tulang hingga 45-50\% selama hidupnya. Penurunan massa tulang tersebut lebih cepat terjadi pada tulang trabekular dibandingkan dengan tulang kortikal. Hal ini disebabkan luas permukaann tulang trabekular lebih besar dari pada tulang kortikal, sehingga metabolisme di bagian tulang trabekular lebih aktif.. ${ }^{13}$

Penelitian ini menunjukkan bahwa pada wanita menopause dengan osteopenia memiliki IMT normal tertinggi (37\%), sedangkan IMT normal pada sampel dengan osteoporosis adalah sebanyak $13 \%$. Hasil penelitian ini sesuai dengan penelitian dari Getha (2014) yang menyatakan bahwa IMT pasien osteoporosis tertinggi pada kategori normal yaitu sebanyak 20 pasien $(69 \%) .{ }^{14}$ Selain itu penelitian yang dilakukan oleh Fawzy (2011) mengenai hubungan antara IMT dengan kepadatan mineral tulang pada pasien yang diperiksa dengan DEXA di Ajman, UAE mendukung adanya penelitian ini. Penelitian tersebut mendapatkan penderita osteopenia terbanyak pada orang dengan indeks massa tubuh yang normal, yakni sebesar $82,4 \%{ }^{15}$ Penelitian Saravi (2013) melaporkan bahwa tidak ada efek signifikan antara berat badan dan IMT, dimana $76,2 \%$ pasien dengan osteoporosis dan osteopenia memiliki IMT yang normal. ${ }^{16}$

Semakin rendah IMT, maka nilai kepadatan tulangnya akan semakin rendah. Keterkaitan antara IMT dengan kepadatan mineral tulang disebabkan oleh adanya efek menyangga tubuh, khususnya pada rangka periferal seperti tulang femur dan tulang radius ultradistal..$^{13}$ Robbins (2006) menyatakan bahwa IMT bukanlah prediktor yang baik untuk kepadatan tulang. ${ }^{17}$ Selain itu, IMT saja tidak dapat secara pasti menggambarkan apakah komposisi tubuh sampel lebih didominasi massa lemak atau massa otot. ${ }^{18}$

\section{SIMPULAN}

Dari segi sosiodemografik, rata-rata usia sampel wanita menopause adalah 52.2 tahun, dengan ratarata riwayat menstruasi terakhir 7 tahun, dengan status pendidikan terakhir berupa perguruan tinggi sebanyak $34 \%$, tidak bekerja sebanyak $42 \%$, dan memiliki riwayat penyakit terbanyak berupa kanker serviks yaitu $49 \%$. Nilai rata-rata $T$-score yaitu $-1,7$ dengan proporsi osteopenia terbanyak sebesar $52 \%$, dibandingkan kepadatan tulang normal (24\%) dan osteoporosis (24\%). Wanita menopause dengan osteopenia memiliki IMT normal terbanyak, sedangkan wanita menopause dengan osteoporosis memiliki IMT normal sebanyak $13 \%$. 


\section{DAFTAR PUSTAKA}

1. Sarianoferni EW. Perbandingan osteoporosis berdasarkan radiomorfometri panoramik antara mandibular cortical index dengan panoramic mandibular index pada pasien di Rumah Sakit Gigi Mulut Universitas Hang Tuah. Fakultas Kedokteran Gigi Universitas Hang Tuah Surabaya; 2015.

2. Syahputra M, Suparman E. Gambaran kadar kalsium wanita menopause di panti werdha Tendean. Fakultas Kedokteran Universitas Samratulangi Manado Bagian Obsetri dan Ginekologi-RSUP Prof. Dr. R. D. Kandou; 2011.

3. Saputra M. Depresi pada wanita menopause dan hubungannya dengan kualitas hidup. Bagian SMF Obsetri dan Ginekologi RSUP Dr. M. Djamil Fakultas Kedokteran Universitas Andalas; 2011.

4. Lash RW, Harrison RV, Jane T, Nicholson JM VL. Osteoporosis: prevention and treatment. Univ Michigan Heal Syst Osteoporos Guidel [Internet]. 2011; Available from: http://www.med.umich.edu/linfo/FHP/practiceguides/ osteoporosis/text.pdf

5. Nanda S, Sudarmiati S. Hubungan antara pengetahuan dan sikap wanita premenopause dengan perilaku pencegahan osteoporosis di Kelurahan Srondol Wetan Kecamatan Bnyumanik Semarang. Program Studi Ilmu Keperawatan Universitas Diponegoro; 2011.

6. Noor Z, Sumitro SB, Hidayat M, Rahim AH SD. Osteoporosis: dasar patomekanisme dan peran mineral atom. Cetakan pe. Tim UB Press. Malang: UB Press; 2011.

7. Ramadan WA. Hubungan densitas mineral tulang dengan kehilangan gigi. Jurnal Repository Unhas. 2014.

8. Damayanti A. Gambaran tingkat pengetahuan osteoporosis pada pegawai administrasi perempuan di Universitas Indonesia tahun 2012. Fakultas Ilmu Keperawatan Program Studi Sarjana; 2012.

9. Tane R. Pengalaman masa menopause ibu Suku Minang di Kotoan Gadang Kota Paakumbuh. Fakultas Keperawatan Universitas Sumatera Utara; 2014.

10. Lukma M. Skrining osteoporosis : hubungan usia dan jenis kelamin gengan kejadian osteoporosis. Research Gate. 2008;10(19):19.

11. Hastuti MF. Konsep diri wanita dewasa madya yang mengalami histerektomi (pengangkatan rahim). Fakultas Psikologi Universitas Gunadarma. Jawa Barat; 2011.
12. Andriani R. Faktor-faktor yang berhubungan dengan kepadatan tulang pada lansia awal di Puskesmas Pisangan Tanggerang Selatan. Program Studi Ilmu Keperawatan Fakultas Kedokteran dan Ilmu Kesehatan Universitas Islam Negeri Syarif Hidayatullah; 2016.

13. Nurchasanah. Faktor faktor yang berhubungan dengan kepadatan mineral tulang pada wanita pascamenopause. Sekolah Pascasarjana Institut Pertanian Bogorr; 2006.

14. Getha CN. Profil pasien osteoporosis di RSUP Fatmawati Jakarta periode Januari 2011-Juli 2014. Program Studi Pendidikan okter Fakultas Kedokteran Dan Ilmu Kesehatan Universitas Islam Negeri Syarif Hidayatullah; 2014.

15. Fawzy T, Muttappallymyalil J, Sreedharan J, et al. Association between body mass index and bone mineral density in patiens referred for dual-energy $\mathrm{x}$-ray absorpmetry Sscan in ajman, uae. J Osteoporos [Internet]. 2011;2011(2011). Available from: https://www.ncbi.nlm. nih.gov/pmc/articles/PMC3135277/

16. Saravi FD, Sayegh F. Bone mineral density and body compositionof adult premenopausal women with three levels of physical activity. J Osteoporos [Internet]. 2013;2013:2013. Available from: http://dx.doi.org/10.1155/2013/953271

17. Robbins J, Schot AM, Azari R, Kronmal R. Body mass index is not a good predictor of bone density : result from whi, chs, and epidos. J Clin Densitom. 2006;9(3):329-34.

18. Setyawati B, Prihatini S, Rochmah W, Pangastuti R. Hubungan indeks massa tubuh dengan densitas mineral tulang pada perempuan dewasa muda (association between body mass index and bone mineral density in young adult female).J Peneliti Gizi dan Makanan [Internet]. 2011;34(2). Available from: Available at: http://ejournal. litbang.depkes.go.id/index.php/pgm/article/view/3099

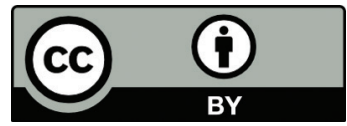

This work is licensed under a Creative Commons Attribution 